\title{
Vergoeding van shockschade sinds de invoering van de Wet vergoeding affectieschade
}

\author{
Een greep uit en op de rechtspraktijk
}

\author{
Mr.A.M. Overbeul*
}

\begin{abstract}
1. Inleiding
Met de inwerkingtreding van de Wet vergoeding affectieschade per 1 januari 2019 hebben naasten en nabestaanden recht op vergoeding van affectieschade ingeval een persoon met wie zij een affectieve band hebben ${ }^{1}$ blijvend ernstig letsel heeft opgelopen of is overleden. ${ }^{2}$ In de literatuur is inmiddels al het een en ander verschenen over hoe deze wet in de praktijk werkt. ${ }^{3} \mathrm{Nu}$ het mogelijk is voor naasten en nabestaanden om vergoeding van affectieschade te vorderen, is het de vraag wat er met de vergoeding van immateriële schade in geval van shockschade gaat gebeuren. Er doen zich nu immers situaties voor waarin naasten en nabestaanden recht kunnen hebben op vergoeding van immateriële schade in de context van zowel shock- als affectieschade. Op deze twee vormen van immateriele schade ligt de nadruk in deze bijdrage.
\end{abstract}

In de literatuur is de verwachting uitgesproken dat deze immateriële schadeposten in beginsel en in lijn met ons wettelijk systeem (zullen) cumuleren. ${ }^{4}$ Maar er zijn ook vragen opgeworpen, zoals de vraag of bij de begroting van immateriële shockschade ten nadele van de benadeelde rekening wordt gehouden met de aan hem of haar toegewezen vergoeding van affectieschade. ${ }^{5}$ Ook is de verwachting uitgesproken dat de

\footnotetext{
Mr. A.M. Overheul is als promovenda verbonden aan het Molengraaff Instituut voor Privaatrecht, het Utrecht Centre for Accountability and Liability Law (UCALL) en Empirical Research into Institutions for Conflict Resolution (ERI) van de Universiteit Utrecht. Haar onderzoek gaat over compensatiesystemen voor beroepsziekten als alternatief voor de klassieke route van het aansprakelijkheidsrecht.

Naast haar promotoren dankt de auteur mr. S.N.P. Wiznitzer voor haar opmerkingen.

1. Deze persoon wordt ook wel 'primair gekwetste' genoemd. Zie bijv. ook C. van der Roest \& J.G. Keijzer, 'De Wet Affectieschade in de praktijk; duidelijke afbakening of onlosmakelijke discussies?', TVP 2020, afl. 2, p. $47-57$.

2. Art. 6:107 en 6:108 BW.

3. Zie bijv. Van der Roest \& Keijzer 2020; E.W. Bosch, 'De wet affectieschade: nader beschouwd', VR 2020/126; E.C.M. Esveld, 'Affectieschade gedekt?', $A V \mho S$ 2019/24, p. 129-134; I. Felix \& A. Schild, 'De vergoeding van immateriële schade in het strafproces', NJB 2020/762.

4. Van der Roest \& Keijzer 2020, p. 56 en voetnoot 90.
}

strafrechter ${ }^{6}$ shockschadevorderingen mogelijk eerder nietontvankelijk zal verklaren, omdat de vordering complex kan zijn, in ieder geval complexer dan vorderingen tot vergoeding van affectieschade. ${ }^{7}$ Verder heeft Lindenbergh de verwachting uitgesproken dat het aantal vorderingen wegens confrontatie met een schokkende gebeurtenis zal afnemen en dat denkbaar is dat naasten en nabestaanden die nu een affectieschadevergoeding kunnen vorderen, de lastigere route van shockschade eerder links laten liggen. ${ }^{8}$ Ook schrijft hij dat het onwaarschijnlijk is dat de Hoge Raad de vereisten voor een aanspraak op shockschade 9 zal verruimen. Hij verwacht dat de Hoge Raad de eisen voor de shockschadevordering, in overeen-

5. Zie bijv. Van der Roest \& Keijzer 2020, p. 56. Van der Roest en Keijzer schrijven daar, onder verwijzing naar het Taxibus-arrest, dat het huns inziens 'niet juist zou zijn om bij de waardering van shockschade (ten nadele van de benadeelde) rekening te houden met een eventueel al ontvangen vergoeding voor affectieschade. Shockschade omvat immers uitdrukkelijk niet de (affectie)schade wegens verdriet dat het overlijden of ernstig gewond raken van een naaste teweeg heeft gebracht.'

6. We zullen zien dat veel zaken waar shock- en/of affectieschade worden gevorderd, zich aandienen voor de strafrechter. Hier kom ik later op terug.

7. Zie S.D. Lindenbergh, “Affectieschade” en "shockschade”, onderscheid, samenloop, vooruitblik', TVP 2018, afl. 4, p. 147. Zie over motivering en redenen voor niet-ontvankelijkheidverklaring bij shockschadevorderingen E.S. Engelhard, M.R. Hebly \& I. van der Zalm, 'De shockschadevordering in het strafproces', TvVP 2015, p. 87-96. De weg van de civiele rechter staat bij een niet-ontvankelijkheidverklaring natuurlijk nog steeds open. Verder is de vordering tot vergoeding affectieschade ook bedoeld om snel, zonder al te veel juridische discussie, te kunnen worden toegewezen. Zie Kamerstukken II 2014/15, 34257, nr. 3, p. 4: 'Bij de vormgeving van het wetsvoorstel geldt voor mij als belangrijk uitgangspunt dat zo veel mogelijk vermeden moet worden dat de vaststelling van de vergoeding van affectieschade leidt tot langdurige en pijnlijke discussies over de intensiteit van het leed.' De verwachting was dan ook dat de regeling in de praktijk niet tot grote uitvoeringsmoeilijkheden leidt en veelal buiten de rechter om kan worden uitgevoerd, zie p. 5-6.

8. Lindenbergh 2018, p. 146. Zie ook p. 147, waar hij schrijft dat enerzijds cumulatie het instellen van beide vorderingen aantrekkelijk kan maken, maar dat anderzijds ook door het in het leven roepen van een smartengeld voor naasten en nabestaanden de noodzaak tot het aanhangig maken van een complexe vordering tot vergoeding van shockschade minder wordt gevoeld. 
stemming met andere jurisdicties, juist nog wat zal aanscherpen. ${ }^{10}$

In deze bijdrage sta ik onder meer stil bij deze in de literatuur opgeworpen punten. Ook besteed ik in het bijzonder aandacht aan het vereiste van 'geestelijk letsel' voor toewijzing van de shockschadevordering. Doel van deze bijdrage is om middels een eerste, verkennende jurisprudentieanalyse inzichtelijk te maken wat speelt op het gebied van vergoeding van immateriële schade in de context van shockschade na inwerkingtreding van de Wet vergoeding affectieschade en hiermee de wetenschap en praktijk verder te helpen. Voor de volledigheid zij opgemerkt dat het doel niet is om een een-op-eenvergelijking te maken met de rechtspraak voor en de rechtspraak na de inwerkingtreding van de Wet vergoeding affectieschade of een overzicht te bieden van alle lagere jurisprudentie op het gebied van shockschade.

De structuur van deze bijdrage is als volgt. Voordat ik toekom aan de verantwoording van de jurisprudentieanalyse (par. 3), bespreek ik het juridisch kader (par. 2). Daarna volgen een analyse (par. $4 \mathrm{t} / \mathrm{m} 8$ ) en een afsluiting (par. 9).

\section{Juridisch kader}

Over de herkomst en reikwijdte van de shock- en affectieschadevordering en hun verhouding tot elkaar is in de literatuur al eerder uitgebreid stilgestaan. ${ }^{11}$ Daarom volsta ik met een korte uiteenzetting van beide vorderingen, te beginnen met de affectieschadevordering.

\subsection{Wet vergoeding affectieschade}

$\mathrm{Na}$ een wetgevingsproces van ongeveer vijftien jaar trad op 1 januari 2019 de Wet vergoeding affectieschade in werking. ${ }^{12}$ Hiermee is een wettelijke grondslag gecreëerd voor smartengeld voor naasten. Het gaat dan om nadeel dat niet in vermogensschade bestaat, maar in leed dat men ondervindt doordat een persoon met wie men een affectieve band heeft, ernstig gewond rakt of overlijdt. ${ }^{13}$ De wet beoogt hiermee te voorzien in erkenning van het leed dat door naasten wordt

9. Lindenbergh spreekt trouwens over de 'aanspraak op schadevergoeding wegens confrontatie met een schokkende gebeurtenis'. Zie over het vermijden van de in de juridische volksmond ontwikkelde terminologie Lindenbergh 2018, par. 2 en S.D. Lindenbergh, Psychische schade, Den Haag: Boom juridisch 2019, p. 72. Zie in dit kader over gedragspresumpties van het recht op vergoeding van shockschade E.F.D. Engelhard \& I.M. Engelhard, 'Shockschade', in: W.H. van Boom, I. Giesen \& A.J. Verheij (red.), Capita civilologie, Den Haag: Boom Juridische uitgevers 2013, p. 517-540.

10. Lindenbergh 2018 , p. 146. Lindenbergh schrijft dat dit kan door 'de aanspraak op volledige schadevergoeding (vermogensschade en ander nadeel) alleen toe te kennen aan degenen van wie op inhoudelijke gronden kan worden gezegd dat zij onder de bescherming van de in casu geschonden norm vallen. Of dat het geval is, zal afhangen van de in kwestie geschonden norm: was het oogmerk van de aansprakelijke gericht op kwetsing van de "geschrokkene", dan is dat reden om onrechtmatigheid ook jegens hem aan te nemen.'

11. Zie Lindenbergh 2018.

12. Stb. 2018, 132 .

13. Aldus de MvT. Zie Kamerstukken II 2014/15, 34257, nr. 3, p. 1. ervaren. ${ }^{14}$ In de wet is een onderscheid gemaakt tussen situaties waarbij een verwant ernstig en blijvend gewond raakt (art. 6:107 lid 2 BW) en waarbij hij of zij overlijdt (art. 6:108 lid $3 \mathrm{BW}) .{ }^{15}$ Belangrijke kenmerken van de wet zijn verder dat hij werkt met een vaste kring van gerechtigden (art. 6:107 lid 3 en 6:108 lid 4 BW) en vaste, gestandaardiseerde, bedragen. ${ }^{16}$ Deze vaste bedragen kunnen worden gevonden in artikel 1 van het Besluit vergoeding affectieschade. ${ }^{17}$ In dit besluit is gedifferentieerd op basis van de relatie tussen de naaste of nabestaande en de primair gekwetste en de vraag of de primair gekwetste ernstig en blijvend letsel ${ }^{18}$ heeft overgehouden aan de onrechtmatige gedraging of is overleden. Als het ernstig en blijvend letsel of het overlijden door een misdrijf is veroorzaakt, worden hogere schadebedragen toegekend. De schadebedragen liggen tussen de $€ 12.500$ en $€ 20.000$. Met het besluit is beoogd te voorkomen dat de vaststelling van de vergoeding van affectieschade leidt tot langdurige en pijnlijke discussies over de intensiteit van het leed. ${ }^{19}$

\subsection{Shockschade}

De vergoeding voor shockschade is in 2002 geintroduceerd met het Taxibus-arrest. ${ }^{20}$ In dit arrest heeft de Hoge Raad bepaald dat indien iemand door overtreding van een veiligheids- of verkeersnorm een ernstig ongeval veroorzaakt, deze persoon niet alleen onrechtmatig handelt jegens degene die dientengevolge is gedood of gekwetst, maar ook jegens degene bij wie door het waarnemen van het ongeval of door de directe confrontatie met de ernstige gevolgen ervan een hevige emotionele schok wordt teweeggebracht. ${ }^{21}$ Voor de vergoeding van immateriële schade is vereist dat uit deze hevige emotionele schok geestelijk letsel voortvloeit, hetgeen zich met name zal kunnen voordoen indien iemand tot wie de aldus getroffene in een nauwe affectieve relatie staat, bij het ongeval is gedood of gewond. ${ }^{22}$ De daardoor ontstane immateriële schade komt op grond van artikel 6:106 onder b BW ${ }^{23}$ voor vergoeding in aan-

14. Kamerstukken II 2014/15, 34257, nr. 3, p. 2. Zie ook p. 4 onder 'Affectieschade'.

15. Kamerstukken II 2014/15, 34257, nr. 3, p. 5.

16. Kamerstukken II $2014 / 15,34257$, nr. 3, p. 4.

17. Te raadplegen via https://wetten.overheid.nl/BWBR0040907/ 2019-01-01. Naar deze 'algemene maatregel van bestuur' wordt verwezen in art. 6:107 lid 2 en 6:108 lid 3 BW.

18. De wetgever heeft in art. 6:107 lid 3 BW ruimte gelaten om bij algemene maatregel van bestuur regels te stellen waarmee nader wordt bepaald wanneer letsel als ernstig en blijvend als bedoeld in lid 1 onder $b$ wordt aangemerkt. De wetgever heeft dit (nog) niet gedaan. Zie over wat ernstig of blijvend letsel is Kamerstukken II 2014/15, 34257, nr. 3, p. 12 e.v. en E.W. Bosch, 'De wet affectieschade: nader beschouwd', $V R$ 2020, p. 207-212.

19. Kamerstukken II 2014/15, 34257, nr. 3, p. 4.

20. HR 22 februari 2002, ECLI:NL:HR:2002:AD5356, NJ 2002/240, m.nt. J.B.M. Vranken (Taxibus). Zie hierover recent ook nog R. Rijnhout, 'Van bijzonder letsel naar bijzondere normschending en beyond', VR 2020/125.

21. Zie over dit vereiste en de sprong van feit naar norm T. Bouwman, 'Empirisch-juridisch onderzoek en de sprong van feit naar norm', $N J B$ 2020, afl. 13 , p. 889.

22. HR 22 februari 2002, ECLI:NL:HR:2002:AD5356, NJ 2002/240, m.nt. J.B.M. Vranken, r.o. 4.3 (Taxibus).

23. Ten tijde van het arrest ging het om art. 6:106 lid 1 onder b BW. 
merking. Daarvoor is, zo oordeelde de Hoge Raad in het Taxibus-arrest:

'vereist dat het bestaan van geestelijk letsel, waardoor iemand in zijn persoon is aangetast, in rechte kan worden vastgesteld, hetgeen in het algemeen slechts het geval zal zijn indien sprake is van een in de psychiatrie erkend ziektebeeld'. ${ }^{24}$

Het vereiste van een in de psychiatrie erkend ziektebeeld voor een vergoeding van immateriële schade is in het Vilt-arrest door de Hoge Raad bevestigd, ${ }^{25}$ en is in de lagere rechtspraak en literatuur als vereiste voor het bestaan van geestelijk letsel gebruikt. In latere arresten van de Hoge Raad is niet meer stilgestaan bij dit vereiste voor het bestaan van geestelijk letsel in de zin van artikel $6: 106$ onder b BW. ${ }^{26}$

Het is de vraag of een in de psychiatrie erkend ziektebeeld nog als vereiste geldt voor het bestaan van geestelijk letsel. In dit kader wijs ik op het EBI-arrest. ${ }^{27}$ Daar geeft de Hoge Raad gezichtspunten op het gebied van vergoeding van immateriële schade, in het bijzonder de aantasting van de persoon in de zin van artikel 6:106 onder b BW (waaronder de shockschadevordering ook wordt beoordeeld). In r.o. 4.2.1 overweegt de Hoge Raad daar als volgt:

'Als de schade die het gevolg is van een onrechtmatige daad nadeel omvat dat niet in vermogensschade bestaat, heeft de benadeelde ingevolge art. 6:106 lid 1, aanhef en onder b, BW recht op een naar billijkheid vast te stellen schadevergoeding indien hij lichamelijk letsel heeft opgelopen, in zijn eer of goede naam is geschaad of op andere wijze in zijn persoon is aangetast.

Van de in art. 6:106 lid 1, onder b, BW bedoelde aantasting in zijn persoon op andere wijze is in ieder geval sprake indien de benadeelde geestelijk letsel heeft opgelopen. Degene die zich hierop beroept, zal voldoende concrete gegevens [curs. AMO] moeten aanvoeren waaruit kan volgen dat in verband met de omstandigheden van het geval psychische schade is ontstaan, waartoe nodig is dat naar objectieve maatstaven het bestaan van geestelijk letsel kan worden vastgesteld (vgl. HR 23 januari 1998, ECLI:NL: HR:1998:ZC2551, rov. 3.4).'

Dezelfde redenering op dit punt zien we in het Gaswinning Groningen-arrest. ${ }^{28}$

24. HR 22 februari 2002, ECLI:NL:HR:2002:AD5356, NJ 2002/240, m.nt. J.B.M. Vranken, r.o. 4.3 (Taxibus).

25. HR 9 oktober 2009, ECLI:NL:HR:2009:BI8583, NJ 2010/387, m.nt. J.B.M. Vranken $($ Vilt $)$, r.o. 3.5.

26. Zo leert een zoekactie via rechtspraak.nl. Gezocht is op 'psychiatrie erkend ziektebeeld', waarbij ik heb gefilterd op uitspraken (geen conclusies) van de Hoge Raad en op civiel recht.

27. HR 15 maart 2019, ECLI:NL:HR:2019:376, NJ 2019/162, m.nt. S.D. Lindenbergh; JIN 2019/69, m.nt. M.E. Witting, r.o. 4.2.1.

28. HR 19 juli 2019, ECLI:NL:HR:2019:1278, r.o. 2.13.2.
Op basis van deze arresten zou naar mijn mening het aanvoeren van voldoende concrete gegevens waaruit kan volgen dat in verband met de omstandigheden van het geval psychische schade is ontstaan, zodat het geestelijk letsel naar objectieve maatstaven kan worden vastgesteld, voldoende kunnen zijn om aan te tonen dat sprake is van geestelijk letsel. ${ }^{29}$ Eerder werd, zoals gezegd ook in het Taxibus-arrest, geschreven dat om het bestaan van geestelijk letsel in rechte vast te stellen het noodzakelijk is dat sprake is van een in de psychiatrie erkend ziektebeeld. $\mathrm{Nu}$ het vereiste van een 'in de psychiatrie erkend ziektebeeld' niet meer zo expliciet wordt genoemd, zou het kunnen dat de Hoge Raad de benadeelde partij tegemoet heeft willen komen bij het bewijzen van zijn of haar geestelijk letsel.

Concreet zou dit alles kunnen betekenen dat het geestelijk letsel ook kan worden onderbouwd met een verklaring van een huisarts. ${ }^{30}$ Een ziektebeeld dat in de psychiatrie is erkend, zou naar mijn weten moeten worden vastgesteld door een psycholoog of psychiater. Hierbij zij opgemerkt dat men hier ook anders over kan denken. In de eerste plaats kan men betogen dat de Hoge Raad een dergelijke omslag op dit punt niet heeft beoogd en dat in de regel nog steeds een in de psychiatrie erkend ziektebeeld is vereist, maar dat maatwerk in sommige gevallen geboden kan worden wanneer een zaak daartoe aanleiding geeft. Ten tweede kan men betogen dat, mocht de Hoge Raad de vereisten voor geestelijk letsel willen versoepelen, deze versoepeling niet voor de shockschadevordering geldt. De shockschadevordering is immers een bijzondere categorie. In de eerste redenering zou ik mij kunnen vinden. Het biedt de feitenrechter de mogelijkheid om met inachtneming van de omstandigheden van het geval tot een redelijke uitkomst te komen. Ook de tweede redenering is te volgen, aangezien de shockschadevordering een bijzonder karakter heeft, in die zin dat het gaat om feitelijk derden in personenschadezaken, voor wie een exclusief vorderingsrecht in de arti-

29. HR 15 maart 2019, ECLI:NL:HR:2019:376, NJ 2019/162, m.nt. S.D. Lindenbergh; JIN 2019/69, m.nt. M.E. Witting, r.o. 4.2.1. Eerder werd, zoals in het Taxibus-arrest (r.o. 4.3), nog het vereiste van een in de psychiatrie erkend ziektebeeld genoemd, maar dat zie ik niet terug in het EBI-arrest en het Gaswinning Groningen-arrest (HR 19 juli 2019, ECLI:NL:HR:2019:1278).

30. Deze redenering lijkt ondersteuning te vinden in een recente conclusie van A-G Aben, waar op het moment van schrijven nog geen arrest van de Hoge Raad bij is gewezen. In de (straf)zaak die voorligt lijdt een benadeelde partij die immateriële schadevergoeding vordert aan PTSSklachten, waarvoor hij zogeheten EMDR-therapie heeft ondergaan. De traumabehandelaar is niet een BIG-geregistreerde psychiater of psycholoog, maar volgens Aben is dat 'niet strikt noodzakelijk, zolang de concrete omstandigheden die wijzen op psychisch letsel voldoende zijn komen vast te staan', zie concl. A-G Aben 12 januari 2021, ECLI:NL:PHR:2021:12, onder 27. Zie anders Hof Arnhem-Leeuwarden 17 december 2019, ECLI:NL:GHARL:2019:10717, r.o. 7.34: 'Nodig is dat voor elk van hen naar objectieve maatstaven het bestaan van geestelijk letsel ten gevolge van de aardbevingen (en wat daarmee samenhangt) wordt aangetoond. Een verklaring van een huisarts of maatschappelijk werker zal daarvoor meestal onvoldoende zijn, omdat er niet zonder meer van kan worden uitgegaan dat die voldoende in staat zijn een psychiatrische diagnose te stellen.' 
kelen 6:107 en 6:108 BW is neergelegd. ${ }^{31}$ Desondanks vraag ik mij af of dan niet de situatie zou kunnen ontstaan dat een (feitelijk) primair benadeelde partij die betoogt aanspraak te maken op een vergoeding van immateriële schade, eerder 'succes' heeft bij een aantasting in de persoon op andere wijze (anders dan shockschade) dan in geval van shockschade van een feitelijk derde - en als dat inderdaad zo is, of dat een wenselijke ontwikkeling is. ${ }^{32}$ In het kader van het laatste is in ieder geval opvallend dat in het strafrechtelijke overzichtsarrest van 28 mei 2019 het vereiste van een in de psychiatrie erkend ziektebeeld voor de onderbouwing van geestelijk letsel ook niet wordt genoemd bij de bespreking van de shockschadevordering aan het eind van r.o. 2.4.5. Daar overweegt de Hoge Raad dat:

'vergoeding van immateriële schade (...) ook [kan] plaatsvinden als door het waarnemen van het strafbare feit of door de directe confrontatie met de ernstige gevolgen ervan, een hevige emotionele schok bij de benadeelde partij is teweeggebracht, waaruit geestelijk letsel voortvloeit, hetgeen zich met name zal kunnen voordoen indien iemand tot wie de aldus getroffene in een nauwe affectieve relatie staat, bij het tenlastegelegde is gedood of gewond (zogenoemde "shockschade"). ${ }^{33}$

Terug naar de vereisten van de shockschadevordering an sich, dus niet alleen concentrerend op de vergoeding van immateriele schade in dat verband. In 2009 heeft de Hoge Raad de criteria voor shockschade bevestigd in het Vilt-arrest, waar een poging om in cassatie het vereiste van 'waarneming van het ongeval of directe confrontatie met zijn ernstige gevolgen' op te rekken, faalde. ${ }^{34} \mathrm{Op}$ basis van dit arrest mogen de aard en de ernst van de normschending niet meespelen bij de beoordeling of is voldaan aan het confrontatievereiste.

31. Zie hierover R. Rijnhout, Schadevergoeding voor derden in personenschadezaken, Den Haag: Boom Juridische uitgevers 2012 en verwijzingen aldaar.

32. Zie als voorbeeld Rb. Rotterdam 18 september 2020, ECLI:NL:RBROT:2020:8205, waar benadeelde 4 (r.o. 8.4), het zoontje van de in deze zaak door een misdrijf om het leven gekomen vader, aanspraak probeert te maken op immateriële schadevergoeding anders dan shockschade. De rechtbank hanteert daar duidelijk een andere maatstaf met betrekking tot het geestelijk letsel dan bij de shockschadevordering van bijv. benadeelde 1 .

33. HR 28 mei 2019, ECLI:NL:HR:2019:793, NJ 2019/379, m.nt. W.H. Vellinga; NbSr 2019/200, m.nt. C.W. van Noorduyn. Zie voor een herhaling van dit arrest bij de strafrechtkamer HR 8 december 2020, ECLI:NL:HR:2020:1955, HR 8 december 2020, ECLI:NL:HR:2020:1956, HR 8 december 2020, ECLI:NL:HR: 2020:1967 en HR 15 december 2020, ECLI:NL:HR:2020:2012.

34. Strekking van het betoog was dat sprake was van opzet bij het gepleegde schadeveroorzakende feit, waardoor minder zware eisen aan de eis van directe confrontatie moeten worden gesteld. Zie voor de klachten in cassatie uitgebreid de conclusie van J. Spier bij HR 9 oktober 2009, ECLI:NL:HR:2009:BI8583, NJ 2010/387, m.nt. J.B.M. Vranken (Vilt). Zie met name r.o. 3.5. Zie ook HR 27 september 2016, ECLI:NL:HR:2016:2201, NJ 2017/88, m.nt. S.D. Lindenbergh, ook genoemd in Lindenbergh 2019, p. 83.
Interessant aan de shockschadevordering is dat het haar bestaansrecht misschien wel ontleent aan de onmogelijkheid affectieschade te vergoeden. ${ }^{35}$ Hierbij zij voor de volledigheid echter wel opgemerkt dat de Hoge Raad met de vergoeding voor shockschade niet heeft beoogd verdriet om het verlies van een naaste te vergoeden. ${ }^{36}$ Belangrijk verschil tussen de shocken affectieschadevordering is dat deze laatste geen zelfstandige onrechtmatigedaadsvordering betreft, maar een afgeleide aanspraak van de onrechtmatige daad jegens de feitelijk primair gekwetste. Daarmee samenhangend is verder van belang dat de shockschadevordering niet alleen voorziet in een vergoeding van immateriële schade, maar ook in de vergoeding van materiële schade die door de shock en confrontatie is ontstaan. ${ }^{37}$ In deze bijdrage staat de vergoeding van shockschade voor immateriële schade centraal. ${ }^{38}$ Een ander belangrijk verschil is de wijze waarop de vorderingen worden begroot. Terwijl de affectieschadevordering, mede door haar genoegdoeningsfunctie, zich kenmerkt door gestandaardiseerde bedragen, wordt de vergoeding van immateriële schade in geval van een shockschadevordering begroot met inachtneming van alle omstandigheden van het geval (concreet). Het gaat dan om de ernst van het verwijt, de aard en ernst van het letsel (bijvoorbeeld duur en intensiteit) en de verwachting ten aanzien van het herstel, en de leeftijd van het slachtoffer. Ook wordt gelet op bedragen die in vergelijkbare gevallen zijn toegewezen. ${ }^{39}$

\section{Verantwoording van de jurisprudentieanalyse}

$\mathrm{Om}$ inzicht te krijgen in wat speelt in de lagere jurisprudentie, is gezocht op de term 'shockschade' in combinatie met 'affectieschade' na 1 januari 2019 via www.rechtspraak.nl. ${ }^{40}$ Op 28 december 2020 leverde deze zoekactie 124 resultaten op. ${ }^{41}$

35. Het is de vraag of, indien de mogelijkheid tot vergoeding affectieschade toen had bestaan, de shockschadepost op dezelfde manier zou zijn ontwikkeld zoals nu is gebeurd. De Hoge Raad overwoog in het Taxibusarrest dat het zijn rechtsvormende taak te buiten zou gaan om tot vergoeding van affectieschade te komen (r.o. 4.2). Wel overwoog de Hoge Raad dat degene die door overtreding van een veiligheids- of verkeersnorm een ernstig ongeval veroorzaakt, ook onrechtmatig handelt jegens degene bij wie door het waarnemen van het ongeval of door de directe confrontatie met de ernstige gevolgen ervan, een hevige emotionele shock teweeggebracht wordt waaruit geestelijk letsel voortvloeit, hetgeen zich met name zal kunnen voordoen indien iemand tot wie de aldus getroffene in een nauwe affectieve relatie staat, bij het ongeval is gedood of gewond (r.o. 4.3). HR 22 februari 2002, ECLI:NL:HR: 2002:AD5356, NJ 2002/240, m.nt. J.B.M. Vranken. Lindenbergh spreekt in het kader van shockschade ook wel over een 'sluiproute'. Zie Lindenbergh 2018, p. 146.

36. HR 22 februari 2002, ECLI:NL:HR:2002:AD5356, NJ 2002/240, m.nt. J.B.M. Vranken (Taxibus), r.o. 4.1-4.3.

37. Deze bijdrage richt zich op smartengeld. Zie hierover en over het overzichtsarrest van de Hoge Raad van 28 mei 2019 (ECLI:NL:HR: 2019:793) ook N.A. Schipper, 'De Hoge Raad over de vordering benadeelde partij: op welke punten is er ruimte over voor verduidelijking en/of heroverweging?', TPWS 2019/101, onder 3 en A.J.J.G. Schijns, 'De vordering van de benadeelde partij in het strafproces: de Hoge Raad geeft college', TVP 2019, afl. 4, p. 111-119, par. 3.2.5.

38. Zie over schadevergoeding voor derden Rijnhout 2012.

39. Zie recent Van der Roest \& Keijzer 2020, p. 56-57.

40. Dat is de datum van de inwerkingtreding van Wet vergoeding affectieschade.

41. Uitgesloten zijn uitspraken van de Hoge Raad en uitspraken van andere instanties binnen het Koninkrijk. 
Daarvan vallen 117 uitspraken in de categorie strafrecht en 7 in de categorie civiel recht. Van de civielrechtelijke uitspraken zijn er 2 bij rechtbanken en 5 bij gerechtshoven gewezen. Bij de categorie strafrecht gaat het om 97 uitspraken bij rechtbanken en 20 uitspraken bij gerechtshoven. Hierbij zij opgemerkt dat niet elke gevonden uitspraak relevant is. De uitspraken zijn in de eerste plaats geselecteerd op basis van het vorderen van zowel shock- als affectieschade door (een van) de benadeelde partij(en). Alleen op deze manier kan immers worden stilgestaan bij de vraag of bij de hoogte van de shockschadevergoeding bijvoorbeeld rekening wordt gehouden met de reeds toegekende affectieschadevergoeding.

De uitspraken zijn geanalyseerd op de hierboven genoemde punten die in de literatuur zijn opgeworpen, maar ook op punten waar in de lagere rechtspraak verschillend mee wordt omgegaan. Het gaat dan om de cumulatie van de shock- en affectieschadevordering, de hoogte van de immateriële schade in het kader van de shockschadevordering, de niet-ontvankelijkheid van de shockschadevordering, het confrontatievereiste en het vereiste van geestelijk letsel (zie hierna par. $4 \mathrm{t} / \mathrm{m} \mathrm{8}$ ). Zoals gezegd is het doel van deze bijdrage om middels een eerste, verkennende jurisprudentieanalyse inzichtelijk te maken wat speelt op het gebied van shockschade na inwerkingtreding van de Wet vergoeding affectieschade. Daarom zijn uitspraken waar alleen shockschade werd gevorderd achterwege gelaten.

$\mathrm{Na}$ het analyseren van elf ${ }^{42}$ willekeurige uitspraken (de eerste steekproef) werd een verzadigingspunt bereikt, waarmee ik bedoel dat na het bestuderen en analyseren van deze elf uitspraken geen nieuwe inzichten of informatie naar voren kwamen. ${ }^{43}$ Omdat ik in dat geval slechts een kleine $10 \%$ van het totale aantal gevonden uitspraken zou hebben geanalyseerd, besloot ik de jurisprudentieanalyse aan te vullen (de tweede steekproef) tot een kwart van het totaal aantal uitspraken, waarbij dezelfde verdeling zoals hierboven weergegeven naar voren komt. ${ }^{44} \mathrm{Bij}$ de tweede steekproef koos ik met hantering van de relevantiefilters (bijvoorbeeld 'strafrecht' en

42. Rb. Rotterdam 19 september 2020, ECLI:NL:RBROT:2020:1460, JA 2020/77, m.nt. E.W. Bosch; Rb. Noord-Holland 23 oktober 2020, ECLI:NL:RBNHO:2020:8510; Rb. Den Haag 27 maart 2020, ECLI:NL:RBDHA:2020:2714; Rb. Den Haag 27 januari 2020, ECLI:NL:RBDHA:2020:450, JA 2020/55, m.nt. E.W. Bosch; Rb Rotterdam 23 oktober 2020, ECLI:NL:RBROT:2020:9481; Rb. Rotterdam 8 september 2020, ECLI:NL:RBROT:2020:8205; Rb. Amsterdam 22 september 2020, ECLI:NL:RBAMS:2020:4640; Rb. Midden-Nederland 20 maart 2020, ECLI:NL:RBMNE:2020:1046; Rb. Overijssel 6 november 2020, ECLI:NL:RBOVE:2020:3666; Hof Amsterdam 8 september 2020, ECLI:NL:GHAMS:2020:2439; Hof Den Haag 23 juli 2019, ECLI:NL:GHDHA:2019:1901, JA 2019/135, m.nt. T. Havekes.

43. Zie hierover K. van den Bos, Empirical legal research. A primer, Cheltenham (VK)/Northampton (VS): Edward Elgar 2020, p. 54.

44. Door het aanhouden van die verdeling is de steekproef (hopelijk) voldoende representatief. 'gerechtshof) telkens één uitspraak, waarna ik er drie oversloeg. ${ }^{45}$

De analyse bestaat in totaal uit 29 strafrechtelijke uitspraken, waarvan 24 bij de rechtbank ${ }^{46}$ en 5 bij het gerechtshof, ${ }^{47}$ aangevuld met twee civielrechtelijke uitspraken, waarvan een bij het gerechtshof ${ }^{48}$ en een bij de rechtbank. ${ }^{49}$

Veel uitspraken laten zich dus vinden bij de strafrechter in het kader van de vordering benadeelde partij (art. $51 \mathrm{f} \mathrm{lid} 2$ Wetboek van Strafvordering (Sv) jo. art. 36f Wetboek van Strafrecht $(\mathrm{Sr})) .{ }^{50}$ Van belang hierbij is dat bij een vordering benadeelde partij de partijen in het strafproces zich dienen te houden aan de civielrechtelijke bewijsregels. ${ }^{51}$ Tegelijkertijd geldt de motiveringsplicht zoals wij die in het civiele proces voor de rechter kennen, ${ }^{52}$ niet voor de strafrechter. Arti-

45. Deze selectiemethode is niet gehanteerd bij de eerste steekproef. Achteraf gezien was dat gelet op de interne validiteit en repliceerbaarheid van het onderzoek beter geweest. Zie hierover ook K. van den Bos, Inleiding empirische rechtswetenschappen, Den Haag: Boom juridisch 2021, p. $75-76$.

46. Rb. Rotterdam 19 september 2020, ECLI:NL:RBROT:2020:1460, JA 2020/77, m.nt. E.W. Bosch; Rb. Noord-Holland 23 oktober 2020, ECLI:NL:RBNHO:2020:8510; Rb. Den Haag 27 maart 2020, ECLI:NL:RBDHA:2020:2714; Rb. Den Haag 27 januari 2020, ECLI:NL:RBDHA:2020:450, JA 2020/55, m.nt. E.W. Bosch; Rb. Rotterdam 23 oktober 2020, ECLI:NL:RBROT:2020:9481; Rb. Rotterdam 8 september 2020, ECLI:NL:RBROT:2020:8205; Rb. Amsterdam 22 september 2020, ECLI:NL:RBAMS:2020:4640; Rb. Midden-Nederland 20 maart 2020, ECLI:NL:RBMNE:2020:1046; Rb. Overijssel 6 november 2020, ECLI:NL:RBOVE:2020:3666; Rb. Den Haag 10 november 2020, ECLI:NL:RBDHA:2020:11332; Rb. Zeeland-West-Brabant 29 januari 2020, ECLI:NL:RBZWB:2020:455; Rb. Rotterdam 18 september 2020, ECLI:NL:RBROT:2020:8205; Rb. Noord-Holland 4 juli 2019, ECLI:NL:RBNHO:2019:5823; Rb. Rotterdam 26 juni 2020, ECLI:NL:RBROT:2020:5609; Rb. Den Haag 14 oktober 2020, ECLI:NL:RBDHA:2020:10201; Rb. NoordNederland 8 juli 2020, ECLI:NL:RBNNE:2020:2387; Rb. Limburg 30 oktober 2020, ECLI:NL:RBLIM:2020:8377; Rb. Rotterdam 3 juli 2020, ECLI:NL:RBROT:2020:5764; Rb. Limburg 12 maart 2019, ECLI:NL:RBLIM:2019:2219; Rb. Rotterdam 23 januari 2020, ECLI:NL:RBROT:2020:473; Rb. Noord-Nederland 22 september 2020, ECLI:NL:RBMNNE:2020:3239; Rb. Oost-Brabant 27 januari 2020, ECLI:NL:RBOBR:2020:393; Rb. Rotterdam 11 december 2019, ECLI:NL:RBROT:2019:9637; Rb. Amsterdam 27 september 2019, ECLI:NL:RBAMS:2019:7229.

47. Hof Amsterdam 5 juli 2019, ECLI:NL:GHAMS:2019:2270; Hof Arnhem-Leeuwarden 1 augustus 2019, ECLI:NL:GHARL:2019:6248; Hof Den Haag 22 oktober 2020, ECLI:NL:GHDHA:2020:2049; Hof Amsterdam 16 november 2020, ECLI:NL:GHAMS:2020:3077; Hof Amsterdam 8 september 2020, ECLI:NL:GHAMS:2020:2439.

48. Hof Den Haag 23 juli 2019, ECLI:NL:GHDHA:2019:1901, JA 2019/135, m.nt. T. Havekes.

49. Rb. Den Haag 30 september 2020, ECLI:NL:RBDHA:2020:10051 (hier werden shock- en affectieschade niet met zoveel woorden gevorderd, maar dat lijkt middels de ambtshalve aanvulling van de rechtsgronden wel zo getoetst door de rechtbank).

50. Zie recent over de geschiktheid van het strafproces voor het afdoen van dergelijke vorderingen J. Janssen, 'Belangrijke keuzes voor het slachtoffer in het strafproces!', NJB 2020/2168.

51. Zie bijv. HR 14 februari 2012, ECLI:NL:HR:2012:BU8755, r.o. 2.3.

52. Zie bijv. Asser Procesrecht/Van Schaick 2 2016/97. 
kel 361 lid 4 Sv schrijft voor dat de beslissing op de vordering van de benadeelde partij met redenen is omkleed. ${ }^{53}$

\section{Cumulatie van de shock- en affectieschadevordering}

Als we naar de rechtspraak kijken, valt in de eerste plaats op dat de shock- en affectieschadevordering, wanneer zij beide voor toewijzing in aanmerking komen, cumuleren. ${ }^{54} \mathrm{Dit}$ is in lijn met ons wettelijk systeem, aangezien de vergoedingen immers van grondslag verschillen. Ook strookt dit met de verwachting die in de literatuur is uitgesproken. Wel is in verschillende uitspraken te zien dat de vergoeding van immateriële schade samenhangend met de shockschadevordering op basis van billijkheid lager wordt toegewezen dan gevorderd. ${ }^{55}$ Of dat in deze zaken met de toegewezen affectieschadevordering te maken heeft, is niet altijd duidelijk, dat wordt in de door mij onderzochte jurisprudentie vaak niet met zoveel woorden gezegd. Eén uitspraak waarin daarover wel expliciet iets is te vinden, betreft een zaak die zich afspeelt voor de rechtbank Noord-Nederland. Daar maakte een moeder aanspraak op een vergoeding van zowel affectieschade als immateriële schade in de context van shockschade en had 'de toewijzing van de affectieschade aan de moeder een matigende werking op het bedrag aan shockschade [van $€ 10.000$; toevoeging AMO] dat de rechtbank redelijk vindt'. ${ }^{56}$

Wat in ieder geval opvalt, is dat door de verdediging in deze zaken, waar de shockschadevordering dus op basis van billijkheid lager is toegewezen, maar ook de affectieschadevergoeding werd toegewezen, een beroep op matiging is gedaan. Zo stelde de verdediging in een zak die speelde voor de rechtbank Rotterdam zich op het standpunt dat de door (een deel van) de benadeelde partijen gevorderde vergoeding van immateriële schade in geval van shockschade diende te worden gematigd, 'gelet op de tevens door hen gevorderde affectieschade'. ${ }^{57}$ De rechtbank gaat in zijn overwegingen niet expliciet in op het verzoek van de verdediging om de vordering tot vergoeding van shockschade te matigen. ${ }^{58}$ Bosch schrijft in zijn noot bij deze uitspraak dat de rechtbank hier wel op had moeten responderen, en dit beroep op matiging niet ongemo-

53. Er is dus geen aansluiting gezocht bij art. 359 lid 2, tweede volzin, Sv. Zie bijv. hierover HR 17 februari 2009, ECLI:NL:HR:2009:BG7762.

54. Rb. Rotterdam 19 september 2020, ECLI:NL:RBROT:2020:1460, JA 2020/77, m.nt. E.W. Bosch; Rb. Noord-Holland 23 oktober 2020, ECLI:NL:RBNHO:2020:8510; Rb. Den Haag 27 maart 2020, ECLI:NL:RBDHA:2020:2714; Rb. Den Haag 27 januari 2020, ECLI:NL:RBDHA:2020:450, JA 2020/55, m.nt. E.W. Bosch; Rb. Rotterdam 23 oktober 2020, ECLI:NL:RBROT:2020:9481; Rb. Limburg 30 oktober 2020, ECLI:NL:RBLIM:2020:8377.

55. Rb. Rotterdam 19 september 2020, ECLI:NL:RBROT:2020:1460, JA 2020/77, m.nt. E.W. Bosch; Rb. Noord-Holland 23 oktober 2020, ECLI:NL:RBNHO:2020:8510; Rb. Noord-Nederland 8 juli 2020, ECLI:NL:RBNNE:2020:2387.

56. Rb. Noord-Nederland 8 juli 2020, ECLI:NL:RBNNE:2020:2387.

57. Rb. Rotterdam 19 september 2020, ECLI:NL:RBROT:2020:1460, JA 2020/77, m.nt. E.W. Bosch, r.o. 8.3.

58. Sieburgh schrijft dat uit het criterium 'kennelijk onaanvaardbare gevolgen' volgt dat de rechter hierbij de nodige terughoudendheid dient te betrachten. Zie Asser/Sieburgh 6-II 2017/179. tiveerd had mogen passeren. Aangezien de vorderingen fundamenteel verschillen, en zoals Bosch schrijft verschillende 'eigen normenkaders' hebben, ${ }^{59}$ is het niet zo gek dat de rechter niet meegaat in het verzoek tot matiging. De rechter heeft deze bevoegdheid op grond van artikel 6:109 BW. Wel stelt de rechter de vergoeding naar billijkheid lager vast dan is gevorderd. ${ }^{60}$ Onduidelijk is of het naar billijkheid lager vaststellen van de vergoeding is ingegeven door de cumulatie van de vorderingen, of dat de shockschadevordering misschien te hoog ingestoken is geweest. Het is verder de vraag of deze motivering, zou deze zaak zich voordoen bij de civiele rechter, de civielrechtelijke motiveringsplicht zou kunnen doorstaan, aangezien niet expliciet wordt ingegaan op het verzoek tot matiging.

Ook voor de rechtbank Noord-Holland verzocht de raadsman van een verdachte de rechtbank om het gevorderde bedrag van $€ 30.000$ voor de immateriële schade vanwege shock te matigen. Naast het toewijzen van de affectieschadevordering van $€ 17.500$, schatte de rechtbank de omvang van de shockschadevergoeding op de voet van artikel 6:106 BW naar billijkheid op $€ 20.000 .^{61}$ Het lijkt erop dat het verzoek tot matiging door de verdediging heeft bijgedragen aan het lager toewijzen van de shockschadevergoeding door de rechtbank.

Uit de uitspraken volgt niet of de toewijzing van de affectieschadevordering de reden is geweest voor het lager laten uitkomen van de vergoeding van immateriële schade vanwege shockschade.

Dat het niet loont om de hoogte van de gevorderde vergoeding van immateriële schade vanwege de shock niet te betwisten, is te zien in de zaak die speelde voor de rechtbank Rotterdam op 23 oktober 2020.62 Daar overwoog de rechtbank dat de 'vordering tot vergoeding van shockschade (...) door de verdediging niet [is] betwist'. De gevorderde shockschadevergoeding van $€ 25.000$ werd, nadat getoetst werd of aan de vereisten was voldaan, in het geheel toegewezen naast de affectieschadevordering. Een betwisting van (de hoogte van) de shockschadevordering ontbrak bijvoorbeeld ook in twee zaken die speelden voor de rechtbank Den Haag, ${ }^{63}$ waarna deze shockschadevordering naast de affectieschadevordering in

59. E.W. Bosch, noot in $J A 2020 / 77$. Zie ook par. 2 hierboven. De vorderingen hebben verschillende grondslagen, roepen verschillende aanspraken in het leven en worden op verschillende wijzen begroot.

60. Benadeelde 1 vorderde $€ 50.000$ aan shockschade, waarvan $€ 30.000$ wordt toegewezen. Benadeelde 4 vorderde eveneens $€ 50.000$ en krijgt $€ 25.000$ toegewezen.

61. Rb. Noord-Holland 23 oktober 2020, ECLI:NL:RBNHO:2020:8510.

62. Rb. Rotterdam 23 oktober 2020, ECLI:NL:RBROT:2020:9481.

63. Rb. Den Haag 27 maart 2020, ECLI:NL:RBDHA:2020:2714 en Rb. Den Haag 27 januari 2020, ECLI:NL:RBDHA:2020:450, JA 2020/55, m.nt. E.W. Bosch. 
haar geheel werd toegewezen. ${ }^{64}$ Het is de vraag of dit ook het geval zou zijn geweest wanneer de hoogte zou zijn betwist of een beroep op matiging zou zijn gedaan door de verdediging. Wat we hier in ieder geval zien, is dat de civielrechtelijke bewijsregels doorklinken in het strafproces en ook door strafrechtadvocaten moeten worden gehanteerd bij de behandeling van de vordering benadeelde partij. Iets dat ingewikkeld kan zijn, aangezien in de strafrechtprocedure de vragen van artikel 348 en 350 Sv centraal staan ${ }^{65}$ - en het lijkt mij dat advocaten zich daar ook voornamelijk op zullen richten - en niet de vordering benadeelde partij.

\section{De hoogte van de vergoeding van immateriële} schade in geval van een shock

Een tweede verwachting die in de literatuur is uitgesproken, is dat de shockschadevergoeding per saldo lager zal uitvallen als affectieschade eveneens voor vergoeding in aanmerking komt. Uit de onderzochte rechtspraak volgt dat in geval van toewijzing van zowel de affectie- als de shockschadevordering ${ }^{66}$ de toegewezen shockschadevordering in $50 \%$ van de gevallen $€ 0$ tot $€ 10.000$ bedraagt, in $12,5 \%$ van de gevallen $€ 10.001$ tot $€ 20.000$ en in $37,5 \%$ van de gevallen $€ 20.001$ tot $€ 30.000$. In zaken waar de affectieschadevordering niet is toegewezen, maar de shockschadevordering wel, ${ }^{67}$ bedraagt de vergoeding in $14,29 \%$ van de gevallen $€ 0$ tot $€ 10.000$, in $71,43 \%$ van de gevallen $€ 10.001$ tot $€ 20.000$ en in $28,57 \%$ van de gevallen $€ 20.001$ tot $€ 30.000$. De shockschadevergoeding valt in de door mij onderzochte zaken iets hoger uit in de categorie tussen $€ 10.000$ en $€ 20.000$ wanneer geen affectieschade wordt toegewezen.

Om iets zinnigs te kunnen zeggen over de hoogte van de gevorderde en uiteindelijk toegewezen vergoeding van immateriële schade vanwege een shock, en om te reflecteren op de vraag of die inderdaad, zoals in de literatuur werd voorspeld,

64. Zie voor een zaak waar de affectieschadevordering niet werd toegewezen, maar de shockschadevergoeding wel, en waar de rechtbank uitdrukkelijk heeft overwogen dat de hoogte van de gevorderde shockschadevergoeding van $€ 20.000$ niet is betwist, Rb. Overijssel 6 november 2020, ECLI:NL:RBOVE:2020:3666, onder de behandeling van de vordering van benadeelde 1 . De vordering wordt integraal toegewezen.

65. M.J. Borgers \& T. Kooijmans, Corstens. Het Nederlands strafprocesrecht, Deventer: Wolters Kluwer 2018, p. 767.

66. Dit betreft de zaken Rb. Den Haag 27 maart 2020, ECLI:NL:RBDHA: 2020:2714; Rb. Den Haag 27 januari 2020, ECLI:NL:RBDHA: 2020:450, JA 2020/55, m.nt. E.W. Bosch; Rb. Limburg 30 oktober 2020, ECLI:NL:RBLIM:2020:8377; Rb. Oost-Brabant 27 januari 2020, ECLI:NL:RBOBR:2020:393; Rb. Noord-Nederland 8 juli 2020, ECLI:NL:RBNNE:2020:2387; Rb. Rotterdam 19 september 2020, ECLI:NL:RBROT:2020:1460; Rb. Noord-Holland 23 oktober 2020, ECLI:NL:RBNHO:2020:8510; Rb. Rotterdam 23 oktober 2020, ECLI:NL:RBROT:2020:9481.

67. Dit betreft de zaken Rb. Overijssel 6 november 2020, ECLI:NL: RBOVE:2020:3666; Rb. Midden-Nederland 20 maart 2020, ECLI:NL:RBMNE:2020:1046; Hof Amsterdam 8 september 2020, ECLI:NL:GHAMS:2020:2439; Rb. Limburg 12 maart 2019, ECLI:NL:RBLIM:2019:2219; Rb. Rotterdam 23 januari 2020, ECLI:NL:RBROT:2020:473; Hof Arnhem-Leeuwarden 1 augustus 2019, ECLI:NL:GHARL:2019:6248; Rb. Den Haag 14 oktober 2020, ECLI:NL:RBDHA:2020:10201; Rb. Oost-Brabant 27 januari 2020, ECLI:NL:RBOBR:2020:393. per saldo lager uitvalt, zou een integrale vergelijking met de situatie van voor 1 januari 2019 op zijn plaats zijn. Dit ligt echter buiten het bestek van deze bijdrage. In ieder geval kan worden gezegd dat de onderzochte rechtspraak in lijn is met de bedragen die sinds 2014-2018 voor immateriële schade vanwege een shock werden vergoed. Zo schreef Lindenbergh in 2018 dat shockschadevergoedingen variëren van $€ 5000$ tot $€ 50.000$, maar sinds 2014 veelal tussen $€ 10.000$ en $€ 40.000$ bedragen. ${ }^{68}$ Van een duidelijke verlaging in de shockschadevergoeding, als eveneens een vergoeding van affectieschade wordt toegewezen, kan mijns inziens dan ook nog niet worden gesproken.

\section{Niet-ontvankelijkheid van de shockschadevordering ${ }^{69}$}

De derde verwachting die in de literatuur werd uitgesproken, was dat de shockschadevorderingen mogelijk eerder niet-ontvankelijk zullen worden verklaard dan voor de intreding van de Wet vergoeding affectieschade, omdat de vordering complex kan zijn, in ieder geval complexer dan vorderingen tot vergoeding affectieschade. De bevestiging of ontkrachting van deze verwachting kan op basis van de hierboven besproken rechtspraak niet plaatsvinden, omdat in deze analyse geen eenop-eenvergelijking met de situatie van vóór 1 januari 2019 is gemakkt. Wat wel gezegd kan worden, is dat in bijna alle zaken waarin een vergoeding voor shockschade niet werd toegewezen, ${ }^{70}$ de rechter oordeelde tot niet-ontvankelijkheid van de shockschadevordering. Motivatie hiervoor werd gevonden in de belasting van het strafproces, ${ }^{71}$ hetgeen inderdaad zou kunnen wijzen op de complexiteit van de shockschadevordering - hoewel dat zo expliciet niet werd gezegd. In een zaak die speelde voor de rechtbank Rotterdam werd de shockschadevordering niet toegewezen omdat niet voldaan was aan het confrontatievereiste, maar oordeelde de rechtbank tot nietontvankelijkheid om 'de mogelijkheid van een gang naar de civiele rechter open [te] houden voor de benadeelde partijen' ${ }^{72}$

68. Lindenbergh 2018, p. 145.

69. Gedeeltelijke niet-ontvankelijkheidverklaringen van de shockschadevergoeding zijn in dit onderzoek niet meegenomen.

70. Rb. Rotterdam 8 september 2020, ECLI:NL:RBROT:2020:8205; Rb. Rotterdam 18 september 2020, ECLI:NL:RBROT:2020:8205; Rb. Noord-Holland 4 juli 2019, ECLI:NL:RBNHO:2019:5823; Rb. Rotterdam 26 juni 2020, ECLI:NL:RBROT:2020:5609; Rb. Rotterdam 3 juli 2020, ECLI:NL:RBROT:2020:5764; Rb. Limburg 12 maart 2019, ECLI:NL:RBLIM:2019:2219 (benadeelde 8); Rb. Rotterdam 23 januari 2020, ECLI:NL:RBROT:2020:473 (benadeelden 1 en 3); Rb. Noord-Nederland 22 september 2020, ECLI:NL:RBMNNE:2020:3239; Rb. Amsterdam 27 september 2019, ECLI:NL:RBAMS:2019:7229; Hof Amsterdam 16 november 2020, ECLI:NL:GHAMS:2020:3077 (benadeelde 2).

71. Zie Rb. Rotterdam 8 september 2020, ECLI:NL:RBROT:2020:8205; Rb. Rotterdam 18 september 2020, ECLI:NL:RBROT:2020:8205; Rb. Noord-Holland 4 juli 2019, ECLI:NL:RBNHO:2019:5823 (benadeelde 2); Rb. Rotterdam 26 juni 2020, ECLI:NL:RBROT:2020:5609; Rb. Rotterdam 23 januari 2020, ECLI:NL:RBROT:2020:473 (benadeelden 1 en 3); Hof Amsterdam 16 november 2020, ECLI:NL:GHAMS: 2020:3077 (benadeelde 2).

72. Rb. Rotterdam 3 juli 2020, ECLI:NL:RBROT:2020:5764, onder 'Hoofdstuk 5: Vorderingen van de nabestaanden'. 
In vijf zaken (in de door mij onderzochte jurisprudentie) heeft de rechter het 'aangedurfd' om te oordelen tot een afwijzing in plaats van een niet-ontvankelijkheidverklaring van de shockschadevordering. ${ }^{73}$ Een beslissing waardoor de gang naar de burgerlijke rechter niet meer openstaat voor partijen, hetgeen overigens niet per se een negatieve consequentie hoeft te zijn. Aan een geding behoort eens (naar civiele maatstaven) een einde te komen. ${ }^{74}$ Mijns inziens was het beter geweest als de strafrechter, in zaken waarbij de kans op toewijzing van de shockschadevordering bij de burgerlijke rechter nihil is, de shockschadevordering had afgewezen in plaats van niet-ontvankelijk had verklaard - ervan uitgaande dat de strafrechter deze inschatting adequaat kan maken. Op deze manier kan aan het civiele geschil voor partijen een einde komen. Hier komt bij dat in zaken waarin de shockschadevordering onvoldoende onderbouwd is door partijen, een niet-ontvankelijkheidverklaring logischer is, om de betreffende partij de kans te geven de vordering deugdelijk te onderbouwen bij de civiele rechter. $^{75}$

\section{Het confrontatievereiste}

Hoe wordt met het confrontatievereiste, door de Hoge Raad geformuleerd als 'de waarneming van het ongeval of directe confrontatie met zijn ernstige gevolgen', omgegaan sinds de Wet vergoeding affectieschade? Is het inderdaad nodig dat de Hoge Raad de eisen voor shockschade, in overeenstemming met andere jurisdicties, aanscherpt? ${ }^{76}$

Over het algemeen kan worden gezegd dat het confrontatievereiste in veel zaken strikt wordt toegepast. Dat wil zeggen dat een shockschadevordering alleen wordt toegekend indien de gelaedeerde het ongeval waarneemt of direct wordt gecon-

73. Rb. Amsterdam 22 september 2020, ECLI:NL:RBAMS:2020:4640; Rb. Limburg 12 maart 2019, ECLI:NL:RBLIM:2019:2219 (benadeelden 11, 12 en 13); Rb. Oost-Brabant 27 januari 2020, ECLI:NL:RBOBR:2020:393 (benadeelde partij, slachtoffer 6); Hof Amsterdam 5 juli 2019, ECLI:NL:GHAMS:2019:2270 (benadeelden 1,2 en 3, die zowel shock- als affectieschadevergoeding hebben gevorderd); Hof Den Haag 22 oktober 2020, ECLI:NL:GHDHA: 2020:2049.

74. Zie hierover bijv. Asser Procesrecht/Giesen 1 2015/387.

75. Zie bijv. Hof Amsterdam 5 juli 2019, ECLI:NL:GHAMS:2019:2270 (benadeelden 1, 2 en 3, die zowel shock- als affectieschadevergoeding hebben gevorderd); Hof Den Haag 22 oktober 2020, ECLI:NL:GHDHA:2020:2049.

76. Lindenbergh 2018, p. 146. fronteerd met de ernstige gevolgen van het ongeval. ${ }^{77}$ In veel zaken zien we dan ook dat de gelaedeerden aanwezig waren bij de schadeveroorzakende gebeurtenis of snel ter plaatse kwamen. ${ }^{78}$

In de zaak die speelde voor de rechtbank Noord-Holland, ${ }^{79}$ waarin ook affectieschade werd toegewezen, werd een ruime maatstaf voor het confrontatievereiste gehanteerd. De directe confrontatie werd namelijk gevonden in de confrontatie die de moeder van het slachtoffer met de politie heeft gehad en de identificatie door de moeder in het mortuarium. Een opvallende verruiming van het confrontatievereiste, juist omdat de moeder ook aanspraak maakte op affectieschadevergoeding en betoogd zou kunnen worden dat juist in die gevallen het confrontatievereiste strikt moet worden gehandhaafd - er is dan immers geen sprake van een schrijnende situatie, waarbij ondanks het bestaan van onrechtmatig handelen (een strafbaar feit) en juridische schade de benadeelde partij zonder vergoeding achterblijft.

Oprekking van het directeconfrontatievereiste tot gevallen waarin sprake is van een identificatie in een mortuarium met het primaire slachtoffer zien we in meer zaken. In veel gevallen gaat het dan om zaken waar affectieschade niet voor vergoe-

77. Zie Rb. Rotterdam 19 september 2020, ECLI:NL:RBROT:2020:1460 JA 2020/77, m.nt. E.W. Bosch; Rb. Den Haag 27 maart 2020, ECLI:NL:RBDHA:2020:2714; Rb. Den Haag 27 januari 2020, ECLI:NL:RBDHA:2020:450, JA 2020/55, m.nt. E.W. Bosch; Rb. Rotterdam 23 oktober 2020, ECLI:NL:RBROT:2020:9481; Rb. Rotterdam 11 december 2019, ECLI:NL:RBROT:2019:9637; Rb. Oost-Brabant 27 januari 2020, ECLI:NL:RBOBR:2020:393 (benadeelde partij, slachtoffer 6); Rb. Rotterdam 23 januari 2020, ECLI:NL:RBROT:2020:473 (benadeelde 2); Rb. Limburg 12 maart 2019, ECLI:NL:RBLIM:2019:2219 (benadeelden 9 en 10); Rb. Noord-Nederland 8 juli 2020, ECLI:NL:RBNNE:2020:2387 (moeder); Rb. Den Haag 14 oktober 2020, ECLI:NL:RBDHA: 2020:10201; Hof Arnhem-Leeuwarden 1 augustus 2019, ECLI:NL:GHARL:2019:6248. Zie voor een afwijzing van de shockschadevordering omdat geen sprake was van directe confrontatie met de gevolgen Rb. Den Haag 10 november 2020, ECLI:NL:RBDHA: 2020:11333 (benadeelde 2, de dochter van het slachtoffer); Rb. Rotterdam 26 juni 2020, ECLI:NL:RBROT:2020:5609; Rb. Noord-Nederland 8 juli 2020, ECLI:NL:RBNNE:2020:2387 (vader en zoon); Rb. Rotterdam 3 juli 2020, ECLI:NL:RBROT:2020:5764; Hof Den Haag 22 oktober 2020, ECLI:NL:GHDHA:2020:2049 (mededeling dat zoon is overleden, is niet genoeg).

78. Zie bijv. Rb. Rotterdam 19 september 2020, ECLI:NL:RBROT: 2020:1460, JA 2020/77, m.nt. E.W. Bosch; Rb. Rotterdam 23 oktober 2020, ECLI:NL:RBROT:2020:9481; Rb. Den Haag 27 januari 2020, ECLI:NL:RBDHA:2020:450, JA 2020/55, m.nt. E.W. Bosch; Rb. Den Haag 27 maart 2020, ECLI:NL:RBDA:2020:2714; Rb. Noord-Nederland 8 juli 2020, ECLI:NL:RBNNE:2020:2387; Rb. Limburg 12 maart 2019, ECLI:NL:RBLIM:2019:2219 (benadeelden 9 en 10); Rb. Rotterdam 23 januari 2020, ECLI:NL:RBROT:2020:473 (benadeelde 2); Rb. Oost-Brabant 27 januari 2020, ECLI:NL:RBOBR: 2020:393 (benadeelde partij, slachtoffer 6); Rb. Rotterdam 11 december 2019, ECLI:NL:RBROT:2019:9637.

79. Rb. Noord-Holland 23 oktober 2020, ECLI:NL:RBNHO:2020:8510. 
ding in aanmerking komt. ${ }^{80}$ Een voorbeeld hiervan is de zaak van het gerechtshof Den Haag, ${ }^{81}$ waarin een vergoeding van affectieschade werd afgewezen omdat het ongeval in kwestie plaatsvond voor inwerkingtreding van de Wet vergoeding affectieschade, maar de vergoeding van immateriële schade vanwege een shock werd toegewezen omdat sprake was van een directe confrontatie met de gevolgen van het ongeval bij de identificatie in het mortuarium in combinatie met het waarnemen van het begin van het ongeval aan de hand van camerabeelden. Ook een identificatie door middel van een foto werd door het gerechtshof Amsterdam ${ }^{82}$ gekwalificeerd als een directe confrontatie met de gevolgen. En ook bij de rechtbank Utrecht was in de zaak over de Utrechtse tramschutter een confrontatie met een foto van het slachtoffer kort na de aanslag, maar voordat zij naar het ziekenhuis werd afgevoerd, voldoende voor het confrontatievereiste. In deze laatste zaak lijken de benadeelden geen affectieschade te hebben gevorderd, omdat bijvoorbeeld geen sprake was van ernstig en blijvend letsel in de zin van artikel 6:107 lid $3 \mathrm{BW} .{ }^{83}$ Het zou kunnen dat dit een reden is geweest voor de rechtbank om een ruimer confrontatievereiste te hanteren. De rechtbank Amsterdam was strenger, en camerabeelden die een van de benadeelden op internet had gezien, werden niet als directe confrontatie gekwalificeerd. ${ }^{84}$ Ook de identificatie van het lichaam van het slachtoffer door een andere benadeelde in het mortuarium werd door de rechtbank in deze zaak niet voldoende geacht om te kwalificeren als directe confrontatie. Hierbij zij opgemerkt dat dit een bewijskwestie kan zijn geweest en dat de rechtbank mogelijk van mening is geweest dat niet aan de stelplicht (en bij voldoende betwisting ook bewijslast) is voldaan.

Wat opvalt is dus dat in de rechtspraak verschillend wordt omgegaan met het invullen van het confrontatievereiste. ${ }^{85} \mathrm{Dit}$ werkt rechtsonzekerheid in de hand en dat is onwenselijk. Wel is het de vraag of de rek die in het confrontatievereiste wordt gevonden, wordt gevoed in zaken waarin de rechter tot een afwijzing van de affectieschadevordering moet komen. In de zaken die hierboven aan de orde kwamen, werd affectieschade niet gevorderd of vond de schadeveroorzakende gebeurtenis plaats voor inwerkingtreding van de Wet vergoeding affectieschade. Het kan dan ook zo zijn dat over een paar

80. Rb. Midden-Nederland 20 maart 2020, ECLI:NL:RBMNE: 2020:1046; Hof Den Haag 23 juli 2019, ECLI:NL:GHDHA: 2019:1901, JA 2019/135, m.nt. T. Havekes; Hof Amsterdam 8 september 2020, ECLI:NL:GHAMS:2020:2439; Rb. Den Haag 14 oktober 2020, ECLI:NL:RBDHA:2020:10201.

81. Hof Den Haag 23 juli 2019, ECLI:NL:GHDHA:2019:1901.

82. Hof Amsterdam 8 september 2020, ECLI:NL:GHAMS:2020:2439.

83. De reden dat dit niet is gebeurd, is mogelijk dat geen sprake is van ernstig en blijvend letsel van de primair gekwetste in de zin van art. 6:107 lid 3 BW. Zie Rb. Midden-Nederland 20 maart 2020, ECLI:NL:RBMNE:2020:1046.

84. Rb. Amsterdam 22 september 2020, ECLI:NL:RBAMS:2020:4640. Aan deze betreffende benadeelde (3) werd echter wel een affectievergoeding toegekend.

85. Zie recent hierover nog A.J. Verheij, 'Ontwikkelingen vergoeding immateriële schade in 2020', VR 2021/2. Zie ook A. Sas, 'Déjà vu: affectieschade', NJB 2017, afl. 26, p. 1823. jaar geen 'noodzaak' meer is tot oprekking van het confrontatievereiste, omdat er minder zaken komen over schadeveroorzakende gebeurtenissen die hebben plaatsgevonden voor 1 januari 2019. Tot die tijd (en dus ook daarna) lijkt het mij verstandig om het confrontatievereiste zoals geformuleerd door de Hoge Raad, dat nogal strikt is, te handhaven. Een eerdere poging tot oprekking werd immers expliciet van de hand gedaan, dus het is de vraag of een ruimer criterium en daarmee oprekking van ons wettelijk systeem stand zal houden in cassatie. ${ }^{86}$

\section{Geestelijk letsel}

Zoals ik hierboven schreef, vraag ik mij af of voor het vereiste van 'geestelijk letsel' nog wel noodzakelijk is dat sprake is van een in de psychiatrie erkend ziektebeeld. ${ }^{87}$ Naar mijn mening zou uit recente jurisprudentie van de Hoge Raad kunnen volgen dat voldoende concrete gegevens, zoals een verklaring van een huisarts, genoeg kunnen zijn om geestelijk letsel aan te nemen (zie par. 2). ${ }^{88}$

Op basis van de jurisprudentie zien we dat vaak wordt vastgehouden aan het vereiste van een in de psychiatrie erkend ziektebeeld, en dat vorderingen tot vergoeding van immateriële schade vanwege een shock worden toegewezen omdat sprake is
86. HR 9 oktober 2009, ECLI:NL:HR:2009:BI8583, NJ 2010/387, m.nt. J.B.M. Vranken ( $V i l t)$.

87. Zie over het vereiste en de wenselijkheid daarvan ook A.M. Overheul, 'Angst als juridisch relevante schade', AV\&S 2017/33, p. 176-185.

88. HR 15 maart 2019, ECLI:NL:HR:2019:376, NJ 2019/162, m.nt. S.D. Lindenbergh; JIN 2019/69, m.nt. M.E. Witting, r.o. 4.2.1. Eerder werd, zoals in het Taxibus-arrest (r.o. 4.3), nog het vereiste van een in de psychiatrie erkend ziektebeeld genoemd, maar dat zie ik niet terug in het EBI-arrest en het Gaswinning Groningen-arrest (HR 19 juli 2019, ECLI:NL:HR:2019:1278). 
van een in de psychiatrie erkend ziektebeeld, ${ }^{89}$ maar ook worden afgewezen omdat daar geen sprake van zou zijn..$^{90}$

In sommige zaken wordt in het midden gelaten of het volgens de rechter noodzakelijk is dat sprake is van een in de psychiatrie erkend ziektebeeld en of daar ook daadwerkelijk sprake van is. ${ }^{91}$ Zo wees de rechtbank Den Haag een vordering tot vergoeding van immateriële schade (in de context van shockschade) toe omdat sprake zou zijn van 'PTSS-klachten', waarvoor 'behandeling nodig [is] gericht op trauma en het rouwproces'. ${ }^{92}$ In een zaak die speelde voor de rechtbank Rotterdam en waar een vergelijkbare vordering werd toegewezen, werd niet ingegaan op of en op welke wijze sprake was van geestelijk letsel, alleen dat dat 'afdoende was onderbouwd'. ${ }^{93}$ Opvallend is dat in deze zaak door de verdediging geen verweer is gevoerd op dit punt, hetgeen reden kan zijn geweest om soepel met dit vereiste om te gaan. ${ }^{94}$

Een zaak waar juist een strenge maatstaf voor een in de psychiatrie erkend ziektebeeld wordt gehanteerd, speelt zich af

89. Rb. Rotterdam 19 september 2020, ECLI:NL:RBROT:2020:1460, JA 2020/77, m.nt. E.W. Bosch; Rb. Noord-Holland 23 oktober 2020, ECLI:NL:RBNHO:2020:8510; Rb. Den Haag 27 januari 2020, ECLI:NL:RBDHA:2020:450, $J A$ 2020/55, m.nt. E.W. Bosch; Rb. Midden-Nederland 20 maart 2020, ECLI:NL:RBMNE:2020:1046. Zie ook Hof Den Haag 23 juli 2019, ECLI:NL:GHDHA:2019:1901, $J A$ 2019/135, m.nt. T. Havekes, waar eisers van de shockschadevordering hun geestelijk letsel nog moeten onderbouwen om aan te tonen dat sprake is van een in de psychiatrie erkend ziektebeeld. Zie ook Hof Amsterdam 8 september 2020, ECLI:NL:GHAMS:2020:2439, waar op basis van het geestelijk letsel van de vader van het primaire slachtoffer ook de moeder van het slachtoffer aanspraak maakt op de gezamenlijk gevorderde shockschadevergoeding; Rb. Noord-Nederland 8 juli 2020, ECLI:NL:RBNNE:2020:2387 (verklaring psycholoog voor PTSS); Rb. Limburg 30 oktober 2020, ECLI:NL:RBLIM:2020:8377 (verklaring psycholoog voor PTSS); Rb. Limburg 12 maart 2019, ECLI:NL:RBLIM:2019:2219 (benadeelden 9 en 10); Rb. Rotterdam 23 januari 2020, ECLI:NL:RBROT:2020:473 (benadeelde 2); Rb. Oost-Brabant 27 januari 2020, ECLI:NL:RBOBR:2020:393 (benadeelde partij, slachtoffer 6); Rb. Rotterdam 11 december 2019, ECLI:NL:RBROT:2019:9637; Hof Arnhem-Leeuwarden 1 augustus 2019, ECLI:NL:GHARL:2019:6248.

90. Rb. Rotterdam 8 september 2020, ECLI:NL:RBROT:2020:8205, waar de vordering van benadeelde 9 echter wel wordt toegewezen omdat sprake is van een in de psychiatrie erkend ziektebeeld; Rb. ZeelandWest-Brabant 29 januari 2020, ECLI:NL:RBZWB:2020:455; Rb. Rotterdam 18 september 2020, ECLI:NL:RBROT:2020:8205; Rb. Noord-Holland 4 juli 2019, ECLI:NL:RBNHO:2019:5823; Rb. Rotterdam 23 januari 2020, ECLI:NL:RBROT:2020:473 (benadeelden 1 en 3); Rb. Noord-Nederland 22 september 2020, ECLI:NL:RBMNNE:2020:3239; Hof Amsterdam 16 november 2020, ECLI:NL:GHAMS:2020:3077 (benadeelde 2).

91. Zie zonder dat wordt vastgesteld of sprake is van geestelijk letsel $\mathrm{Rb}$. Overijssel 6 november 2020, ECLI:NL:RBOVE:2020:3666.

92. PTSS-klachten lijken wat anders te zijn dan een in de psychiatrie erkend ziektebeeld. Rb. Den Haag 27 maart 2020, ECLI:NL:RBDHA: 2020:2714.

93. Rb. Rotterdam 23 oktober 2020, ECLI:NL:RBROT:2020:9481.

94. Rb. Rotterdam 23 oktober 2020, ECLI:NL:RBROT:2020:9481. Zie in dit kader ook Rb. Amsterdam 23 december 2020, ECLI:NL:RBAMS: 2020:6643, waar [zoon 2] een shockschadevordering van $€ 50.000$ kreeg toegewezen zonder dat sprake was van een in de psychiatrie erkend ziektebeeld. Deze uitspraak viel niet binnen de steekproef, maar werd aangedragen door de redactie. voor de rechtbank Zeeland-West-Brabant. ${ }^{95}$ Daar is slachtoffer 2, als benadeelde gevoegd in het strafproces, getuige van een schietpartij op slachtoffer 1 en zelf ternauwernood aan de dood ontsnapt. Informatie van behandelaren van de benadeelde over zijn geestelijk letsel ter onderbouwing van de vordering tot vergoeding van immateriële schade in verband met een shock is volgens de rechtbank niet genoeg. Om de schade te onderbouwen moet volgens de rechtbank sprake zijn van 'een onafhankelijke (door de beide partijen gezamenlijk of door de rechter te benoemen) deskundige (een psychiater)' en kan niet '(zonder meer) [worden] afgegaan op informatie van behandelaren van de benadeelde'. Mogelijke reden voor deze strenge maatstaf is dat de verdediging de shockschadevordering heeft betwist, 'aangezien [slachtoffer 2] zich nog maar kort geleden heeft gemeld bij de GGZ, terwijl er al veel tijd is verstreken sinds het feit'. De rechtbank verklaart de vordering niet-ontvankelijk, aangezien 'nader partijdebat ter vaststelling van eventuele shockschade in de hiervoor bedoelde zin een onevenredige belasting [zou] vormen voor het strafproces'. Het is de vraag of deze strenge benadering, met een uitgebreid partijdebat over de geestelijke toestand van de benadeelde partij, inclusief extra kosten voor een onafhankelijk psychiater, wenselijk is - terwijl in deze zaak vaststaat dat de benadeelde partij (ook slachtoffer) getuige is geweest van een fatale schietpartij. Hier kan tegenin worden gebracht dat het vereiste van geestelijk letsel met zich meebrengt dat enkel de confrontatie met een schokkende gebeurtenis niet voldoende is en daarmee waarborgt dat alleen schade die als juridisch relevant wordt beschouwd voor vergoeding in aanmerking komt.

In ieder geval zij opgemerkt dat daadwerkelijk soepelere vereisten voor het geestelijkletselcriterium ook gevolgen zouden kunnen hebben voor toewijzing van de smartengeldvordering in geval van een shockschadesituatie. Het is de vraag of dat wenselijk is. Wat in ieder geval wenselijk is, is rechtszekerheid, ook op dit punt.

\section{Afsluiting}

In deze bijdrage reflecteerde ik op de (vergoeding van immateriële schade in de context van een) shockschadevordering sinds de invoering van de Wet vergoeding affectieschade. Doel van deze bijdrage was om middels een eerste, verkennende analyse een overzicht te bieden van de stand van zaken op het gebied van shockschade na inwerkingtreding van de Wet vergoeding affectieschade en met dit overzicht de wetenschap en praktijk verder te helpen. De uitspraken zijn geanalyseerd op basis van de cumulatie van de shock- en affectieschadevordering, de hoogte van de vergoeding van immateriële schade in geval van een shockschadevordering, de niet-ontvankelijkheid van de shockschadevordering, het confrontatievereiste en het vereiste van geestelijk letsel. Aan dit laatste vereiste kwam bijzondere aandacht toe bij de bespreking van het juridisch kader.

95. Rb. Zeeland-West-Brabant 29 januari 2020, ECLI:NL:RBZWB: 2020:455. 
Op hoofdlijnen kan worden gezegd dat de shock- en affectieschadevordering, zoals verwacht werd in de literatuur en in lijn is met ons wettelijk systeem, cumuleren. Van een duidelijke verlaging in de vergoeding van immateriële schade in geval van een shock, als eveneens affectieschade voor vergoeding in aanmerking komt, kan mijns inziens nog niet worden gesproken. De uitspraken die ik heb bestudeerd en de bedragen die daarin werden toegekend, lijken in lijn te zijn met wat eerder door rechters, voor de invoering van de Wet vergoeding affectieschade, werd toegewezen. De vergoeding bij een shock lijkt niet lager uit te vallen door toewijzing van de affectieschadevordering.

Wanneer de shockschadevordering door de strafrechter niet wordt toegekend, wordt deze door hem vaak niet-ontvankelijk verklaard, ook wanneer mijns inziens duidelijk is dat de vordering bij (de nog openstaande route naar) de burgerlijk rechter zal stranden. Wellicht is een afwijzing in dergelijke gevallen meer op zijn plaats om aan het (civiele) geschil voor alle partijen een einde te laten komen. Tegelijkertijd zorgt dit er mogelijk voor dat een benadeelde partij meer is aangewezen op de strafrechter, en de civiele rechter zich soms niet in een bepaald debat (bijvoorbeeld over de voorwaarden van geestelijk letsel) zal kunnen mengen - hetgeen de rechtsontwikkeling mogelijk weer niet ten goede komt.

In de rechtspraak wordt verschillend omgegaan met de invulling van het confrontatievereiste. Soms vindt om onduidelijke reden een oprekking plaats - in een aantal gevallen lijkt die oprekking voort te komen uit de onmogelijkheid om affectieschade te vergoeden. In ieder geval lijken die oprekkingen mij niet in lijn met de jurisprudentie van de Hoge Raad. Ook met het vereiste van geestelijk letsel wordt door rechters verschillend omgegaan, en is het mijns inziens de vraag of het algemene vereiste van een in de psychiatrie erkend ziektebeeld nog wel opgaat, of dat geestelijk letsel ook met voldoende (andere) gegevens kan worden onderbouwd, zoals een verklaring van een huisarts of misschien zelfs getuigenverklaringen. Op beide punten is rechtszekerheid gewenst. 